\title{
The Level of Performance of Science Teachers in the Sultanate of Oman in Light of NSTA Standards from their Point of View
}

\author{
Adnan Salem ALdoulat ${ }^{1}$, Abdullah Saif AlTobi ${ }^{2} \&$ Ahmed Al-Fawair ${ }^{3}$ \\ ${ }^{1}$ University of Jordan, Educational Sciences school, Department of Curriculum and Instruction, Jordan \\ ${ }^{2}$ A'sharqiyah University, College of Arts and Humanities, Sultanate of Oman \\ ${ }^{3}$ University of Nizwa, Faculty of Science and Arts, Department of Education and Human Studies, Sultanate of \\ Oman \\ Correspondence: Adnan Salem ALdoulat, University of Jordan, Educational Sciences School, Department of \\ Curriculum and Instruction, Jordan. E-mail: adnan_doulat@yahoo.com
}

Received: August 4, 2018

doi:10.5539/mas.v12n10p58

\author{
Accepted: August 14, 2018 \\ Online Published: September 13, 2018 \\ URL: https://doi.org/10.5539/mas.v12n10p58
}

\begin{abstract}
The study aimed to know The Level of Performance of Science Teachers in the Sultanate of Oman in Light of NSTA Standards from their Point of View. The study sample consisted of (126) science male and female teachers in the al-dakhliah governorate in the Sultanate of Oman for the academic year 2016/2017. The researchers developed a questionnaire to determine the level of performance of science teachers in light of NSTA standards, which consisted of 83 paragraphs divided into five standards. The results of the study indicate that the level of performance of science teachers was moderate. The results indicated that the highest level performance of science teachers was in teachers' knowledge and understanding of content, followed by the standard of understanding how students learn and use different methods to develop their knowledge. While the lowest level of performance of science teachers in the effective planning of educational units standard. The results also showed no significant differences in the performance of science teachers attributed to the gender variable or specialization variable, while there are differences of statistical significance attributed to the variable qualification scientific and for the benefit of Masters, and the existence of differences of statistical significance attributed to the variable number of years of service and for teachers who have years of experience more than ten years.
\end{abstract}

Keywords: level of performance, science teacher, NSTA Standards

\section{Introduction}

The tremendous evolution of the world of knowledge and technology has played a major role in changing the roles of the science teacher at the moment. Where these roles vary according to the educational stage and the developmental characteristics of the students. Having been our sole source and source of information, he has become a facilitator and facilitator of learning.

The teacher in general and the science teacher in particular, one of the most important components contributing to the development of the educational process. As one of the most important objectives of teaching science is to improve the student's mental, skillful and emotional development and to integrate his personality in all its aspects, the performance of the science teacher has become necessary so that he will be able to employ curricula and school programs and to create a suitable environment for learning science. Other. In addition to increasing the teacher's awareness of the same strengths and weaknesses, and the efficiency and ability to deliver information to his students. Therefore, it is necessary to determine the level of science teacher, by comparing it with the performance standards of teachers used in developed countries.

The science teacher is in need of more in-depth knowledge, more knowledge about the methods of teaching science that help them develop higher mental processes for students, and they need to develop their abilities and skills in using modern methods of measuring and evaluating students' achievement (Nashwan, 2001).

Hence, developed countries such as the United States of America began in 1989 to set standards for teaching science based on several assumptions, the most important: the need to change the educational system, and attention to how to train students to learn, the teacher to deepen the understanding of students. 
In 1995, national standards for science education were published to represent a vision of officials and decisionmakers, to judge current teaching methods of science, and a basis for the design of school science programs (Troberg, Bailey et al., 2004).

In 1998, the National Science Teachers Association (NSTA) identified ten standards for professional development programs based on national standards in scientific education related to the professional development of science teachers: the criterion of preparing science teachers "content"; the nature of science; the survey; the scientific context; Education; curriculum; social context; assessment; learning environment; and professional practice (Brownstein, Allan, Hagevik, Shane \& Veal, 2009).

In 2003, the National Association of Science Teachers adopted only five standards derived from the previous standards (Veal \& Allan, 2014) as follows:

1- The teacher is effective if he or she demonstrates an understanding of science, knowledge and practices of contemporary science and deals with students by interpreting important concepts, ideas and applications through content analysis.

2- The teacher is effective if he uses various methods and means, including scientific research and the development of knowledge to train students on how to learn science.

3-The teacher is considered effective if the plans for the educational units are designed to be consistent with the objectives of teaching the science set by the state and the competent educational bodies.

4-The teacher is considered to be effective if he is able to create a safe learning environment for all students, especially when using chemicals, the ethical treatment of living organisms in the classroom and the implementation of emergency procedures.

5- The teacher is considered to be effective if he is able to demonstrate students' understanding of the main scientific concepts, principles, theories and laws through the final formative assessment processes.

Several Arab foreign studies have been conducted on the performance of science teachers in light of NSTA standards,

The study included the study of Zuabi and Salamat (2008), which aims to investigate the extent to which science teachers possess Jordanian standards for the development of teachers professionally from their point of view and from the point of view of school principals and science supervisors. The sample included 50 teachers in all disciplines (chemistry, physics, biology, And the environment) of Bachelor's degree holders and above who study science for the upper secondary grades (eighth, ninth and tenth). The survey included seven areas: (Education in Jordan - Academic Knowledge - Teaching Planning - Implementation of Teaching - Assessment of Students 'Learning - Self Development - Ethics of Education). The study found that the total arithmetic mean of science teachers' marks reached $82.6 \%$, and the percentage of responses School principals and supervisors are $71.8 \%$ and $63.6 \%$ respectively. The results showed no differences due to the variable of experience. There are differences between the average responses of teachers, managers and supervisors.

The study of Al-Ghamdi (2010) aimed at evaluating the performance of natural science teachers in the middle stage in light of the international standards of scientific education. The results indicated that the practice of science teachers in all fields in light of the international standards of scientific education was weak, and that the practice of natural science teachers in the intermediate stage in light of the international standards of scientific education was absent in the field of planning of teaching, and a weak degree of implementation of teaching and evaluation, Professional teacher. The results also indicate that there are no statistically significant differences in the degree of natural science teachers in the middle stage of the standards of international scientific education in the fields of (planning for teaching, implementation of lessons, assessment and utilization of results, professional teacher) and the total degree of practice according to the different (qualification, specialization, quorum Teaching, training courses), and the existence of statistically significant differences according to different years of experience in favor of teachers with more than 12 years of experience.

Al-Khatib (2012) conducted a study aimed at determining the level of performance of science teachers in the stage of empowerment and starting in light of the standards of (NSTA) from the point of view of educational supervisors and school principals and teachers themselves in the governorates of Gaza. The analytical descriptive method was used to collect data, The availability of NSTA standards in the performance of science teachers reached (66.74\%) from the point of view of educational supervisors below the expected level, (78.47\%) from the principals 'point of view, and $84.3 \%$ from the teachers' point of view. The study also pointed to the absence of statistically significant differences in performance level due to gender, specialization, number of training courses, school stage and number of years of experience, while the study indicated that there are statistically significant differences in performance 
due to the academic qualification for the bachelor's campaign with educational preparation.

The Al-Abdullah study (2015) aimed at evaluating physics teachers in light of NSTA standards from the point of view of specialist supervisors. The study sample consisted of (28) supervisors of physics. A questionnaire consisting of (32) paragraphs has been applied to the NTSA standards. The results showed that the criterion (survey) had the lowest rates (58\%) and the criterion (professional growth) by (69). The criterion (the nature of science), the standard of teaching skills, the syllabus and the standard of occupational safety achieved the same percentage (75\%). The content criterion and the evaluation criterion scored $81 \%$ (Physical issues) at the highest rate(\%88) .

The role of science teacher has undergone several changes and developments depending on the type of curriculum. The role of the science teacher in the beginning was to present information to the students according to the textbook without any enrichment, modification or development, and to change the role of science teacher. The science teacher is no longer the sole source of knowledge, The student has to use the methods of exploration through which to reach the truth, how to connect them together, and then access to generalizations. Therefore, the knowledge and competencies of the science teacher at this stage must be more profound and broad as the assistance of students in the development of mental processes, and the high skill of using scientific activities to access the basic principles in science, and the skill of measuring the achievement of students, so the role of the teacher to provide advanced educational materials Students help them shift from theoretical to practical in the field, and provide them with feedback to correct their course (Khatib, 2012).

\section{The Problem of the Study and its Questions}

The learning process is based on three axes: content, student and teacher. Some studies, such as the Lulu study (2007), emphasized the focus on content through an evaluation study of science curricula using international standards, in which the physics topics included in science books were analyzed. Other studies, such as the study of the Baz (2005), aimed to develop the science curriculum at the basic stage in light of the student-centered science learning standards, indicating low levels of student achievement in the international test (TIMSS). Therefore, it was necessary to reconsider the process of evaluation, and focus on the third axis and the teacher to be a comprehensive assessment process and integrated assessment of the science teacher is one of the areas of important educational evaluation, which was confirmed by the study of Salah (2004) the need for standards to raise the level of teacher performance (Audet, 2000; Huber, 2001) that the training of the science teacher and the work to improve the performance of the teacher must be in light of a real assessment objectively and scientifically, through the use of global standards in science education as a basis for the development of teacher Science professionally and develop its performance in light of these standards. The problem of this study is determined by evaluating the performance of science teachers in the internal province of the Sultanate of Oman in light of the level of NSTA standards from their point of view, by answering the following questions of the study:

1- What is the level of performance of science teachers in the al-dakhliah governorate in the Sultanate of Oman in light of the standards of NSTA?

2- Are there statistically significant differences at $(\alpha=0.05)$ in the level of performance of science teachers in the al-dakhliah governorate in the Sultanate of Oman in light of the NSTA standards due to the variables (gender, qualification, specialization and number of years of service)?

3- Are there statistical differences at $(\alpha=0.05)$ in the level of performance of science teachers in the al-dakhliah governorate in the Sultanate of Oman on each of the standards of NSTA due to the variables (gender, qualification, specialization, number of years of service)?

\section{Objectives of the Study}

The present study sought to achieve the following objectives:

-Determining the level of performance of science teachers in the al-dakhliah governorate in the Sultanate of Oman in light of the standards of NSTA.

-Identification of statistical differences in the level of performance of science teachers in the al-dakhliah governorate in the Sultanate of Oman in light of the standards of NSTA according to gender variables, scientific qualification, specialization, and the number of years of service.

-Identifying the statistical differences in the level of performance of science teachers in the al-dakhliah governorate in the Sultanate of Oman in light of the standards of NSTA according to the variables of the study on each of the following standards: teachers knowledge and understanding of the content, understanding how students learn and use different methods to develop their knowledge, Create a safe learning environment and learning experiences for all students to achieve safety and security, effective evaluation. 


\section{Importance of the Study}

The present study draws on the importance of the topic it addressed, namely, evaluating the performance of science teachers in light of NSTA standards. Therefore, the present study is a new addition to the researches and studies that dealt with evaluating the level of performance of science teachers.

On the other hand, the current study draws on the importance of the target sample, the of science teachers in the Sultanate of Oman, where no previous study - to the knowledge of researchers - dealt with the assessment of the performance of science teachers in light of the standards of NSTA in Oman in general, In particular, it helps to draw the attention of educational officials and decision-makers in the Sultanate of Oman to the importance of adopting the NSTA standards in the evaluation of science teachers in the various education departments in the Sultanate of Oman.

The present study also described and analyzed the performance of science teachers in light of international standards. This enables the officials and decision makers in Oman to benefit from the results of the present study in developing and improving the performance of teachers and improving their level through the preparation of programs and workshops based on the results of the present study. The current study has paved the way for researchers interested in this field to carry out future studies, including the preparation and implementation of training programs to improve the performance of science teachers in the Sultanate of Oman.

\section{Study Limits and Determinants}

The results of the current study were limited to teachers of science at the General Directorate of Education in the al-dakhliah governorate in the Sultanate of Oman for the academic year 2016/2017.

The results of the study were determined by the responses of the sample members to the study tool (the determination of the level of performance of science teachers in light of the NSTA standards) developed by the researchers.

The results of the current study are also determined by the characteristics of the study and the statistical procedures used.

\section{Study Terms}

Performance Level: Any role, behavior, or practice undertaken by the teacher in order to achieve his educational goals and objectives, which can be measured by determining the level of performance of science teachers in light of the NSTA standards developed by the researchers.

\section{NSTA standards: (National Science Teachers Association)}

Are five standards developed by the US National Council and the National Association of Science Teachers to develop science teacher programs by describing what the science teacher should know and what to do while teaching science? These are: teachers' knowledge and understanding of content; understanding how students learn and using different approaches to developing their knowledge; effective classroom planning; creating a safe learning environment and learning experiences for all students to achieve security and safety;

\section{Methodology of the Study}

This study is a descriptive study which aims to describe and evaluate the performance level of science teachers in the al- dakhliah governorate in the Sultanate of Oman in light of the standards (NSTA). The study relied on quantitative research (questionnaire) in the collection and analysis of study data. A questionnaire was used to determine the level of performance of science teachers in light of the NSTA standards for collecting data from science teachers in the governorate of Oman.

\section{Study Society}

A community of all male and female science teachers in the al-dakhliah governorate in the Sultanate of Oman on their opinion on the actual performance of science teachers in light of the NSTA standards for the academic year 2016/2017, the number of (805) teachers and according to the statistics of the General Directorate of Education in the al- dakhliah governorate

\section{The Study Sample}

The sample of the study consisted of (126) male and female science teachers who were selected by simple random way. This constitutes $16 \%$ of the study population. Table (1) shows the distribution of the sample of the study according to gender variables, scientific qualification, specialization and number of years of service. 
Table 1 . Sample of the study divided by the variables of the study

\begin{tabular}{llll}
\hline percentage & Number of teachers & Category & variable \\
\hline $38.9 \%$ & 49 & male & gender \\
$61.1 \%$ & 77 & female & \\
$60.3 \%$ & 76 & Bachelor degree & qualification \\
$28.6 \%$ & 36 & Bachelor degree + qualification & \\
$11.1 \%$ & 14 & Master & \\
$41.3 \%$ & 52 & chemistry & \\
$28.6 \%$ & 36 & physics & \\
$30.2 \%$ & 38 & Biology & Number of working years \\
$15.1 \%$ & 19 & $1-5$ & \\
$34.1 \%$ & 43 & $6-10$ & \\
$50.8 \%$ & 64 & More than 10 & \\
\hline
\end{tabular}

\section{Study Tool}

The process of selecting the current study tool went through several steps as follows:

1- Review the educational literature on the performance of science teachers in light of NSTA standards, and previous studies that focused on determining the level of performance of science teachers in light of the standards of NSTA from the perspective of the teachers themselves.

2-Adopting a questionnaire to determine the level of performance of science teachers in light of NSTA standards prepared by Al-Khatib (2012), which consisted of (102) paragraphs divided into five standards.

3-Some necessary modifications were made to the original questionnaire in accordance with the characteristics of the sample. Some paragraphs were deleted and other paragraphs were clarified.

4- Presenting the questionnaire in its preliminary modified form (90 paragraph) to a group of arbitrators to verify the validity of the content of the study instrument.

5-Verify the stability of the study instrument by calculating the internal consistency coefficient - alpha kronbach.

The current study tool consisted of (83) paragraphs divided into five areas (standards) as follows:

-The first standard: knowledge and understanding of the teachers of the content and the number of paragraphs (19) paragraph.

-The second standard: understanding how students learn and use different methods to develop their knowledge and the number of paragraphs (14) paragraph.

-The third standard: Effective planning of the educational units and the number of paragraphs (17) paragraph.

-The Fourth standard: creating a safe learning environment and learning experiences for all students to achieve security and safety and the number of paragraphs (15) paragraph.

-The fifth criterion: effective evaluation and the number of paragraphs (18) paragraph.

In the answer to the questionnaire, the researchers asked the science teachers to determine their level of performance in light of the NSTA standards according to the following five-dimensional Likert scale (very little exercise $=1$, little exercise $=2$, medium exercise $=3$ ), Exercise is very large $=5$ ).

\section{The Veracity of the Study Tool}

To validate the content of the study tool, it was presented to six faculty members at Nizwa University in Oman and five science teachers. There have been some observations and amendments proposed by the Committee of Arbitrators was the deletion of some paragraphs and clarify some of them to become the final number of paragraphs of the scale (83) paragraph. There was consensus on the adequacy of the paragraphs and the applicability of the questionnaire to the target sample.

\section{Stability of the Study Tool}

In order to calculate the stability of the study instrument, the researchers applied the study tool to a survey sample from outside the study sample, consisting of (40) teachers. The internal consistency coefficient (Kronbach-alpha) was then calculated to contain the scale at multiple levels of the answer. Where the value of Cronbach Alpha for the study tool as a whole (0.96). The internal consistency coefficient - Kronbach Alpha was calculated for each standard separately, as shown in Table (2). 
Table 2. Kronbach-Alpha coefficient values for the study tool as a whole and for each tool standards

\begin{tabular}{lll}
\hline $\begin{array}{l}\text { The value of the Kronbach } \\
\text { Alpha }\end{array}$ & Number of paragraphs & standards for resolution \\
\hline 0.96 & 83 & Total scale \\
0.90 & 19 & $\begin{array}{l}\text { Teacher knowledge and understanding of content } \\
\text { Understand how students learn and use different } \\
\text { methods to develop their knowledge }\end{array}$ \\
0.86 & 14 & $\begin{array}{l}\text { Effective planning of educational units } \\
\text { Create a safe learning environment and learning } \\
\text { experiences for all students to achieve safety and } \\
\text { security } \\
0.93\end{array}$ \\
0.84 & 17 & authentic evaluation \\
0.86 & 18 &
\end{tabular}

Table (2) indicates that the stability coefficients of the questionnaire as a whole and the five criterion standards were high and acceptable for study purposes.

\section{Data Analysis Method}

After collecting the data, the responses were emptied and the statistical analyzes needed for the data were carried out by computer using the Statistical Analysis Program (SPSS). The statistical averages and standard deviations of the estimates of the individuals of the study sample were calculated for each paragraph of the questionnaire, and each of the standards for determining the level of performance of science teachers in light of the NSTA standards in order to answer the first question. To answer the second question, Independent-Samples T-test analysis and ANOVA were used. Finally, the Multivariate Multivariate Analysis Test (MANOVA) was used to answer the third question.

\section{Results of the Study and Discussion}

The researchers used a questionnaire to determine the level of performance of science teachers in light of the NSTA standards for collecting data from science teachers in Oman's al-dakhliah governorate about their opinion of the actual performance of science teachers in light of the NSTA standards to answer the study questions.

\subsection{Results of the first question}

What is the level of performance of science teachers in the al-dakhliah governorate in the Sultanate of Oman in light of the standards of NSTA?

To answer this question, the arithmetical averages and standard deviations of the questionnaire as a whole were calculated for each criterion.

For the purposes of the current study, the degree to which science teachers have NSTA standards has been determined by subtracting the minimum of alternatives (1) from the upper limit of alternatives (5) to output (4). The result of the difference between the upper and lower limits (4) was divided by 5 levels. The levels of ownership of the sample were determined as follows:

$$
\begin{aligned}
& \text {-Non level }=1 \text { to } 1.80 \\
& \text { Lowe level }=1.81 \text { to } 2.61 \\
& \text {-moderate level }=2.62 \text { to } 3.42 \\
& \text {-high level }=3.43 \text { to } 4.23 \\
& \text {-Very high level }=4.24 \text { to } 5
\end{aligned}
$$

\begin{tabular}{|c|c|c|c|c|c|}
\hline Rank & $\begin{array}{l}\text { Level of } \\
\text { Performance }\end{array}$ & $\begin{array}{l}\text { standard } \\
\text { deviation }\end{array}$ & MEAN & $\begin{array}{l}\text { Number } \\
\text { paragraphs }\end{array}$ & Standard \\
\hline ------ & Average & 0.40 & 3.14 & 83 & a questionnaire \\
\hline 1 & Average & 0.52 & 3.19 & 19 & $\begin{array}{l}\text { Teacher knowledge and } \\
\text { understanding of content }\end{array}$ \\
\hline
\end{tabular}

Table 3. The arithmetical averages and standard deviations of respondents' responses to the questionnaire as a whole

Each of the standard for determining the level of performance of science teachers in light of the standards of NSTA 
Average

2

5

Average

Average

4

3
0.46

0.58

3.06

3.13

3.14
14

18
Understand how students

learn and use different methods to develop their knowledge

Effective planning of educational units Create a safe learning environment and learning experiences for all students to achieve safety and security AUTHENTIC EVALUATION

Table (3) shows the arithmetical averages and standard deviations of respondents' responses to the questionnaire as a whole and to each of the standard for determining the level of performance of science teachers in light of NSTA standards. The results of the present study indicate that the performance of the science teachers in the aldakhliah governorate in the Sultanate of Oman in light of the standards of the (NSTA) on the questionnaire as a whole and all five standards was average, where the average score of the sample on the questionnaire as a whole $(3,14)$ standard deviation of $(0,40)$ as shown in Table $(3)$.

The researchers attributed the lack of performance of science teachers in light of the standards (NSTA) to high levels to assign teachers to many administrative work that limits its creativity and reflected negatively on the level of performance, such as additional quotas and participation in activities in addition to the number of hours and classes assigned. The researchers also believe that the conviction of science teachers in the traditional methods of teaching and lack of modern and effective strategies and methods of teaching and how to apply can be a cause of their average performance. In addition to the lack of material incentives that have a great role in encouraging the science teacher to creativity, innovation and development. The results showed that the highest performance of the science teachers in the al-dakhliah governorate in Oman in light of the standards of (NSTA) was in the standard of knowledge and understanding of teachers of content, where the average scores of the sample 3.19 and standard deviation 0.52 , followed by the standard of understanding how to learn students And the use of various methods to develop their known with an average of 3.18 and a standard deviation of 0.46 . The researchers attribute this to the pre-service training courses and workshops held by the Ministry of Education and Learning in Oman for new teachers before they attend school, in addition to ongoing training workshops throughout the academic year during the period of service. These workshops and workshops are designed to educate science teachers and familiarize them with the content of the curriculum and analyze it. In addition to the Ministry of Education to provide teachers of science guide teacher to help them understand the content and how to learn the students.

On the other hand, the lowest performance of science teachers in the al-dakhliah governorate in the Sultanate of Oman in light of the standards (NSTA) in the standard planning effective units with an educational average of 3.06 and a standard deviation 0.58 . The researchers believe that the low performance of science teachers in this standard may be due to the lack of focus of the courses and workshops and workshops held by the Ministry of science teachers in the pre-service and in service on the effective planning of educational units. Researchers also attribute the fact that the programs of preparing science teachers at universities and colleges do not focus sufficiently on the practical and applied aspect of effective planning. The lack of effective classroom planning is also attributed to the increase in the number of students per class, and the large volume of book content the teacher must complete during the school year limits the teacher's ability to effectively plan the units.

\subsection{Results of the Second Question}

Are there differences of statistical significance at $(\alpha=0.05)$ in the level of performance of science teachers in the al-dakhliah governorate in the Sultanate of Oman in light of the NSTA standards attributed to variables (gender, qualification, specialization and number of years of service)?

To answer this question, Independent-Samples T-test analysis was used to determine whether there was an effect on the performance of science teachers in the al-dakhliah governorate in the Sultanate of Oman in light of the NSTA standards Table 4. 
Table 4. (T-test), arithmetic averages, and standard deviations of the gender variable

\begin{tabular}{|c|c|c|c|c|c|c|c|c|c|}
\hline $\begin{array}{l}\text { Level of } \\
\text { significance }\end{array}$ & $\begin{array}{l}\text { Degrees } \\
\text { freedom }\end{array}$ & of & $\begin{array}{l}\mathrm{T} \\
\text { value }\end{array}$ & $\begin{array}{l}\mathrm{F} \\
\text { value }\end{array}$ & $\begin{array}{l}\text { standard } \\
\text { deviation }\end{array}$ & MEAN & sample & Category & variable \\
\hline 0.995 & 124 & & $0.007-$ & 0.247 & $\begin{array}{l}0.40 \\
0.39\end{array}$ & $\begin{array}{l}3.14 \\
3.14\end{array}$ & $\begin{array}{l}49 \\
77\end{array}$ & $\begin{array}{l}\text { Male } \\
\text { female }\end{array}$ & gender \\
\hline
\end{tabular}

The results of the present study, as shown in Table (4), showed no statistically significant differences at a level of significance of less than 0.05 in the level of performance of male science teachers (arithmetic average $=3.14$, standard deviation $=0.40$ ) Female science (arithmetic mean $=3.14$, standard deviation $=0.39$ ), and the statistical significance level was 0.995 . The researchers attributed this to the fact that the teachers and teachers of science in the Sultanate of Oman to the same preparation programs, whether in the pre-service, whether the preparation at the university or training workshops given to them before school, or programs and workshops during training service.

The researchers used the ANOVA to determine whether there was an impact on the performance of science teachers in the internal education sector in the Sultanate of Oman in light of the NSTA standards. There is an independent variable (three degrees) Education, MA.

Table 5. Analysis of the unitary variance, arithmetic averages and standard deviations of the scientific qualification variable

\begin{tabular}{|c|c|c|c|c|c|c|c|}
\hline \multicolumn{2}{|c|}{ Analysis of mono - variance } & \multirow{2}{*}{ Homogeneity of contrast } & \multirow{2}{*}{ standard deviation } & \multirow{2}{*}{ MEAN } & \multirow{2}{*}{ sample } & \multirow{2}{*}{ Category } & \multirow{2}{*}{ variable } \\
\hline Level of significance & $\mathrm{F}$ & & & & & & \\
\hline \multirow[t]{3}{*}{$* 0.000$} & 16.01 & 0.68 & 0.35 & 3.10 & 76 & Bachelor degree & \multirow{3}{*}{ Qualification } \\
\hline & & & 0.39 & 3.04 & 36 & Bachelor degree +qualification & \\
\hline & & & 0.31 & 3.65 & 14 & Master & \\
\hline
\end{tabular}

The results of the study, as shown in Table (5), showed that there were statistically significant differences at a level of significance less than (0.05) in the level of performance of science teachers in the al-dakhliah governorate in the Sultanate of Oman in light of the NSTA standards according to the variable of scientific qualification.

The results of the statistical analysis using the Tukey comparisons indicated that the performance of science teachers with a master's degree (arithmetic average $=(3.65)$, standard deviation $=(0.31)$ was significantly higher than that of science teachers holding a bachelor's degree (arithmetic mean $=(3,10)$, standard deviation $=(0.35)$ and the performance of science teachers holding a bachelor's degree and undergoing the educational qualification program (arithmetical mean $=(3,04)$, standard deviation $=(0.39)$. While there were no statistically significant differences between the performance of science teachers who hold bachelor's degrees and science teachers who hold a bachelor's degree and have undergone an educational qualification program.

The researchers attributed the high performance of science teachers who hold master's degrees to the fact that the Master's program in universities focuses more on providing science teachers with the methods and methods of teaching modern science compared with the programs of preparing teachers in the bachelor and educational qualification.

The researchers also used the ANOVA to determine if there was an effect on the level of performance of science teachers in the al-dakhliah governorate in the Sultanate of Oman in light of the NSTA standards because there is an independent variable (specialization) comprising three categories (chemistry, physics, biology).

Table 6. Analysis of mono-variance, arithmetic mean and standard deviations of specialization variable

\begin{tabular}{|c|c|c|c|c|c|c|c|}
\hline \multicolumn{2}{|c|}{ Analysis of mono - variance } & Homogenei & \multirow{2}{*}{$\begin{array}{l}\text { standard } \\
\text { deviation }\end{array}$} & \multirow[b]{2}{*}{ MEAN } & \multirow[b]{2}{*}{ sample } & \multirow[b]{2}{*}{ Category } & \multirow[b]{2}{*}{ variable } \\
\hline Level of significance & F value & $\begin{array}{l}\text { ty of } \\
\text { contrast }\end{array}$ & & & & & \\
\hline \multirow[t]{3}{*}{0.14} & 1.99 & 0.46 & 0.40 & 3.22 & 52 & chemistry & Major \\
\hline & & & 0.32 & 3.06 & 36 & physics & \\
\hline & & & 0.46 & 3.10 & 38 & Biology & \\
\hline
\end{tabular}


As shown in Table (6), there were no statistically significant differences at a level of significance less than 0.05 in the level of performance of chemistry teachers in the al-dakhliah governorate in the Sultanate of Oman in light of the NSTA standards $($ mean $=(3.22)$, standard deviation $=(0,40)$, physics teachers' performance (arithmetical mean $=(3,06)$, standard deviation $=(0.32)$, and performance of biology teachers $($ mean $=(3.10)$, standard deviation $=$ (0.46).

The researchers attribute this finding to similar pre-service and in-service preparation programs for physics, chemistry and biology teachers. The three courses (physics, chemistry, biology) are interrelated, being combined together in the first level in a single book called Science.

The researchers also used the ANOVA to determine if there was an effect on the performance of the science teachers in the Sultanate of Oman in light of the NSTA standards because there was an independent variable (number of years of service) 5 years, more than 5 - 10 years, more than 10 years.

Table 7. Analysis of the unitary variance, arithmetic averages and standard deviations of the variable number of years of service

\begin{tabular}{|c|c|c|c|c|c|c|c|}
\hline \multicolumn{2}{|c|}{ Analysis of mono - variance } & \multirow{2}{*}{ Homogeneity of contrast } & \multirow{2}{*}{ standard deviation } & \multirow{2}{*}{ MEAN } & \multirow{2}{*}{ sample } & \multirow{2}{*}{ Category } & \multirow{2}{*}{ variable } \\
\hline Level of significance & $F$ value & & & & & & \\
\hline \multirow[t]{3}{*}{$* 0.04$} & 3.280 & 0.40 & 0.40 & 3.06 & 19 & $5-1$ & Number of years in service \\
\hline & & & 0.38 & 3.05 & 43 & $10-6$ & \\
\hline & & & 0.36 & 3.23 & 64 & More than 10 & \\
\hline
\end{tabular}

The results of the study, as shown in Table (7), showed that there were statistically significant differences at a level of significance less than (0.05) in the level of performance of science teachers in the al-dakhliah governorate in the Sultanate of Oman in light of the NSTA standards according to the number of years of service

The results of the statistical analysis using Tukey comparisons indicated that the performance level of science teachers with more than ten years of experience (mean $=(3.23)$, standard deviation $=(0.36)$ was significantly higher than that of science teachers with five years of experience Or less (mean $=3.06$, standard deviation $=(0.40)$ and the level of performance of science teachers who have more than five years of experience and up to 10 years (mean $=(3.05)$, standard deviation $=(0.38)$, while There were no statistically significant differences between the level of performance of science teachers who have five years experience or less and the performance of science teachers who have more Five years experience until ten years.

The more experienced science teachers are, the greater the level of their performance in light of the NSTA standards. The experience contributes to the teachers' ability to provide modern and effective teaching and evaluation skills and to implement them in practice while teaching materials within classes.

\subsection{Results of the Third Question}

Are there any statistically significant differences in the level of performance of science teachers in the al-dakhliah governorate in the Sultanate of Oman on each of the NSTA standards due to the variables (gender, qualification, specialization, and number of years of service)?

To answer this question, the mean and standard deviations of each of the standard for determining the level of performance of science teachers were calculated in light of the five NSTA standards. The analysis of the variable variance between groups (MANOVA) was conducted to determine if there were statistically significant differences in the level of performance of science teachers in the al-dakhliah governorate in Oman according to gender variable on each of the five standards. The statistical significance level was adjusted and corrected to 0.01 using the Bonferroni correction equation. The statistical analysis of the dependent variables (the five standards for the questionnaire) was then performed separately.

Table 8. Analysis of the multivariate variance between groups (MANOVA) of the gender variable according to the five standards of the questionnaire

\begin{tabular}{llllllll}
\hline $\begin{array}{l}\text { Level of } \\
\text { significance }\end{array}$ & $\begin{array}{c}\text { Value } \\
\text { of } \mathrm{F}\end{array}$ & $\begin{array}{l}\text { Degrees } \\
\text { freedom }\end{array}$ & $\begin{array}{c}\text { Total } \\
\text { squares }\end{array}$ & $\begin{array}{c}\text { standard } \\
\text { deviation }\end{array}$ & Mean & Gender & The dependent variable \\
\hline 0.52 & 0.411 & 1 & 0.111 & 0.51 & 3.23 & male & Tndependent \\
variable
\end{tabular}




\begin{tabular}{|c|c|c|c|c|c|c|c|}
\hline 0.82 & 0.050 & 1 & 0.010 & 0.54 & 3.17 & male & \multirow{2}{*}{$\begin{array}{l}\text { Understand how students learn and use different } \\
\text { methods to develop their knowledge }\end{array}$} \\
\hline & & & & 0.40 & 3.19 & female & \\
\hline \multirow[t]{2}{*}{0.24} & 1.375 & 1 & 0.464 & 0.64 & 2.99 & male & \multirow{2}{*}{ Effective planning of educational units } \\
\hline & & & & 0.54 & 3.11 & female & \\
\hline \multirow[t]{2}{*}{0.48} & 0.498 & 1 & 0.097 & 0.49 & 3.17 & male & \multirow{2}{*}{$\begin{array}{l}\text { Create a safe learning environment and learning } \\
\text { experiences for all students to achieve safety and } \\
\text { security }\end{array}$} \\
\hline & & & & 0.41 & 3.11 & female & \\
\hline \multirow[t]{2}{*}{0.85} & 0.034 & 1 & 0.007 & 0.52 & 3.15 & male & \multirow{2}{*}{ AUTHENTIC EVALUATION } \\
\hline & & & & 0.43 & 3.14 & female & \\
\hline
\end{tabular}

Table (8) shows that there are no statistically significant differences at the mean level of 0.01 among the average responses of science teachers in the al-dakhliah governorate in the Sultanate of Oman to each of the five standards of the questionnaire due to gender variable. The value of the test (Wilks' Lambda) $=(0.957)$, the value of $\mathrm{P}=$ $(1,089)$, and the level of significance $=(0.37)$.

As for the variable of scientific qualification, Table (9) shows that there are statistically significant differences at the level of significance of (0.01) among the average responses of science teachers to the five standards of the questionnaire according to the scientific qualification (BA, BA, MA). The value of the test (Wilks' Lambda) = (0.625), the value of $\mathrm{P}=(6,306)$, and the level of significance $=(0.000)$.

Table 9. Analysis of the variable variance between groups (MANOVA) of the scientific qualification variable according to the five standards of the questionnaire

\begin{tabular}{|c|c|c|c|c|c|c|c|c|}
\hline $\begin{array}{l}\text { Level of } \\
\text { significance }\end{array}$ & $\begin{array}{l}\mathrm{F} \\
\text { value }\end{array}$ & $\begin{array}{l}\text { Degrees } \\
\text { of } \\
\text { freedom }\end{array}$ & $\begin{array}{l}\text { Total } \\
\text { squares }\end{array}$ & $\begin{array}{l}\text { standard } \\
\text { deviation }\end{array}$ & Mean & qualification & dependent variable & $\begin{array}{l}\text { Independent } \\
\text { variable }\end{array}$ \\
\hline \multirow[t]{3}{*}{$* 0.004$} & \multirow[t]{3}{*}{5.784} & \multirow[t]{3}{*}{2} & \multirow[t]{3}{*}{2.884} & 0.50 & 3.17 & $\begin{array}{l}\text { Bachelor } \\
\text { degree } \\
\text { Bachelor+ } \\
\text { qualification }\end{array}$ & \multirow[t]{3}{*}{$\begin{array}{l}\text { Teacher knowledge and } \\
\text { understanding of content }\end{array}$} & \multirow{13}{*}{ Qualification } \\
\hline & & & & 0.51 & 3.08 & & & \\
\hline & & & & 0.47 & 3.60 & master & & \\
\hline \multirow[t]{2}{*}{$* 0.007$} & \multirow[t]{2}{*}{5.122} & \multirow[t]{2}{*}{2} & \multirow[t]{2}{*}{1.997} & 0.45 & 3.17 & $\begin{array}{l}\text { Bachelor } \\
\text { degree } \\
\text { Bachelor+ } \\
\text { qualification }\end{array}$ & $\begin{array}{l}\text { Understand how students } \\
\text { learn and use different } \\
\text { methods to develop their } \\
\text { knowledge }\end{array}$ & \\
\hline & & & & 0.35 & 3.52 & Master & \multirow{4}{*}{$\begin{array}{l}\text { Effective planning of } \\
\text { educational units }\end{array}$} & \\
\hline \multirow[t]{3}{*}{$* 0.000$} & \multirow[t]{3}{*}{26.708} & \multirow[t]{3}{*}{2} & \multirow[t]{3}{*}{12.794} & 0.42 & 3.01 & $\begin{array}{l}\text { Bachelor } \\
\text { degree } \\
\text { Bachelor+ } \\
\text { qualification }\end{array}$ & & \\
\hline & & & & 0.64 & 2.83 & & & \\
\hline & & & & 0.36 & 3.93 & Master & & \\
\hline \multirow{5}{*}{$* 0.000$} & \multirow[t]{2}{*}{7.652} & \multirow[t]{2}{*}{2} & \multirow[t]{2}{*}{2.697} & 0.44 & 3.08 & $\begin{array}{l}\text { Bachelor } \\
\text { degree } \\
\text { Bachelor+ } \\
\text { qualification }\end{array}$ & \multirow[t]{2}{*}{$\begin{array}{l}\text { Create a safe learning } \\
\text { environment and learning } \\
\text { experiences for all students } \\
\text { to achieve safety and } \\
\text { security }\end{array}$} & \\
\hline & & & & 0.32 & 3.54 & Master & & \\
\hline & \multirow[t]{3}{*}{9.617} & \multirow[t]{3}{*}{2} & \multirow[t]{3}{*}{3.667} & 0.41 & 3.06 & $\begin{array}{l}\text { Bachelor } \\
\text { degree } \\
\text { Bachelor+ } \\
\text { qualification }\end{array}$ & \multirow[t]{3}{*}{$\begin{array}{l}\text { AUTHENTIC } \\
\text { EVALUATION }\end{array}$} & \\
\hline & & & & 0.47 & 3.14 & & & \\
\hline & & & & 0.48 & 3.61 & Master & & \\
\hline
\end{tabular}


As for the specialization variable, Table (10) shows that there are statistically significant differences at the mean level of 0.01 among the average responses of physics teachers in the al-dakhliah governorate in Oman, the average responses of the chemistry teachers and the average of the biology teachers' responses to the third criterion Educational) for the benefit of physics teachers. The value of the test (Wilks' Lambda) $=(0.837)$, the value of $\mathrm{P}$ $=(2,215)$, and the level of significance $=(0.01)$.

Table 10. Analysis of the variance between the different groups (MANOVA) of the specialization variable according to the five standards of the questionnaire

\begin{tabular}{|c|c|c|c|c|c|c|c|c|}
\hline $\begin{array}{l}\text { Level of } \\
\text { significance }\end{array}$ & $\begin{array}{l}\mathrm{F} \\
\text { value }\end{array}$ & $\begin{array}{l}\text { Degrees } \\
\text { of } \\
\text { freedom }\end{array}$ & $\begin{array}{l}\text { Total } \\
\text { squares }\end{array}$ & $\begin{array}{l}\text { standard } \\
\text { deviation }\end{array}$ & MEAN & qualification & The dependent variable & $\begin{array}{l}\text { Independent } \\
\text { variable }\end{array}$ \\
\hline \multirow[t]{4}{*}{0.62} & 0.484 & 2 & 0.262 & 0.56 & 3.23 & chemistry & $\begin{array}{l}\text { Teacher knowledge and } \\
\text { understanding of content }\end{array}$ & \\
\hline & & & & 0.54 & 3.19 & physics & & \\
\hline & & & & 0.43 & 3.12 & Biology & & \\
\hline & & & & & & chemistry & $\begin{array}{l}\text { Understand how students } \\
\text { learn and use different } \\
\text { methods to develop their }\end{array}$ & \\
\hline \multirow[t]{3}{*}{0.09} & 2.485 & 2 & 1.009 & 0.40 & 3.92 & & knowledge & \\
\hline & & & & 0.40 & 3.09 & physics & & \\
\hline & & & & 0.55 & 3.13 & Biology & & \\
\hline \multirow[t]{4}{*}{$* 0.008$} & 4.989 & 2 & 3.170 & 0.55 & 3.18 & chemistry & $\begin{array}{l}\text { Effective planning of } \\
\text { educational units }\end{array}$ & Major \\
\hline & & & & 0.48 & 2.81 & physics & & \\
\hline & & & & 0.65 & 3.14 & Biology & & \\
\hline & & & & & & chemistry & $\begin{array}{l}\text { Create a safe learning } \\
\text { environment and learning } \\
\text { experiences for all students }\end{array}$ & \\
\hline \multirow[t]{3}{*}{0.37} & 0.994 & 2 & 0.388 & 0.36 & 3.20 & & $\begin{array}{l}\text { to achieve safety and } \\
\text { security }\end{array}$ & \\
\hline & & & & 0.44 & 3.08 & physics & & \\
\hline & & & & 0.45 & 3.09 & Biology & & \\
\hline \multirow[t]{3}{*}{0.16} & 1.892 & 2 & 0811 & 0.44 & 3.23 & chemistry & Authentic evaluation & \\
\hline & & & & 0.36 & 3.13 & physics & & \\
\hline & & & & 0.57 & 3.04 & Biology & & \\
\hline
\end{tabular}

Table (10) indicates that there are no statistically significant differences at the level of significance of 0.01 among the average responses of physics teachers, chemistry teachers and biology teachers on the first standard (teachers' knowledge and understanding of content) and the second standard (understanding how students learn) The use of different methods to develop their knowledge), the fourth standard (creating a safe learning environment and learning experiences for all students to achieve safety and security) and the fifth standards (effective evaluation).

Table (11) shows that there are statistically significant differences at the mean level of (0.01) among the average responses of the science in the al-dakhliah governorate in the Sultanate of Oman, who do not exceed five years of experience and the average responses of science teachers who have more than Five years and less than ten years, and the average responses of science teachers with more than ten years experience on the first standards (teachers' knowledge and understanding of content) for science teachers who have more than ten years experience. The value of the test $($ Wilks' Lambda $)=(0.807)$, the value of $\mathrm{P}=(2,685)$, and the level of significance $=(0.004)$.

Table 11. Analysis of the variable variance between groups (MANOVA) for the variable number of years of service according to the five standards of the questionnaire

\begin{tabular}{lllllllll}
\hline $\begin{array}{l}\text { Level of } \\
\text { significance }\end{array}$ & $\begin{array}{l}\mathrm{F} \\
\text { value }\end{array}$ & $\begin{array}{l}\text { Degrees of } \\
\text { freedom }\end{array}$ & $\begin{array}{l}\text { Total } \\
\text { squares }\end{array}$ & $\begin{array}{l}\text { standard } \\
\text { deviation }\end{array}$ & MEAN & Experience & The dependent variable \\
\hline$* 0.000$ & 8.893 & 2 & 4.275 & 0.53 & 2.91 & $5-1$ & Teacher & knowledge \\
variable & and & Number & of \\
\hline
\end{tabular}




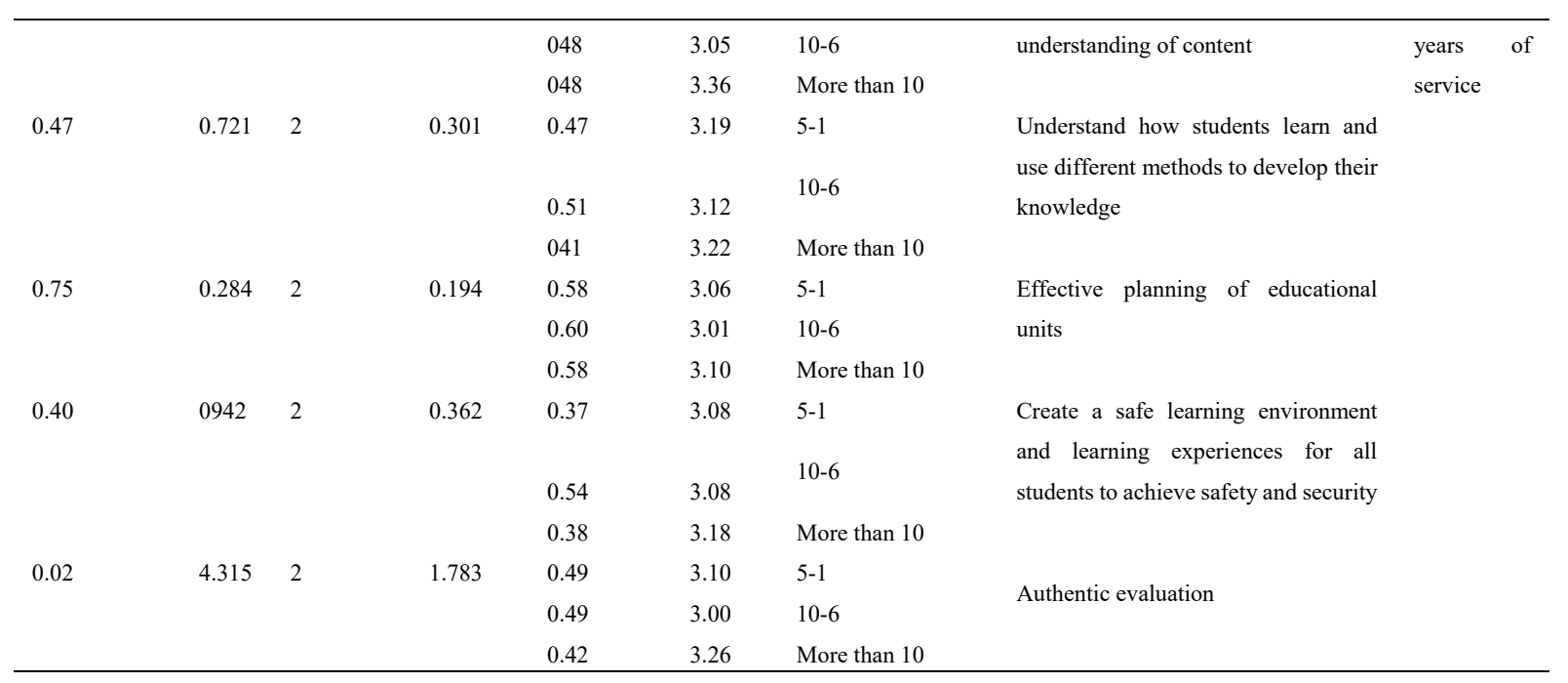

There were no statistically significant differences at the level of significance of 0.01 among the average responses of science teachers in the al-dakhliah governorate in Oman according to the number of years of service on the second standard (understanding how students learn and using different methods to develop their knowledge) (Effective planning of educational units), the fourth standard (creating a safe learning environment and learning experiences for all students to achieve security and safety) and the fifth standard (effective evaluation).

\section{Recommendations}

In light of the researchers recommend the following:

1- Conduct studies and research on the level of science teachers possessing NSTA standards in the Sultanate of Oman as a whole.

2- Conduct studies and research on the level of the acquisition of science teachers to NSTA standards from the point of view of educational supervisors and school principals in the Sultanate of Oman.

3- Teacher training programs include NSTA standards.

\section{References}

Al-Abdullah, H. K. (2015). Physics teachers' calendar in light of NSTA standards of face. The Journal of Basic Education for Educational and Human Sciences, 20.

Al-Ghamdi, S. (2010). A survey entitled "Evaluation of the performance of natural science teachers in the middle stage in light of the international standards of scientific education" unpublished doctoral thesis, Faculty of Education, Umm Al-Qura University, Saudi Arabia.

Al-Khatib, R. (2012), the level of performance of science teachers in the stage of empowerment and starting in light of the standards (NSTA) from the point of view of educational supervisors and school principals and teachers themselves in the governorates of Gaza, MA.

Allan, E., Shane, J., Brownstein, E. M., Ezrailson, C., Hagevik, R., \& Veal, W. (2009). Using performance-based assessments to prepare safe science teachers. Journal of Science Teacher Education, 20(6), 495.

Audet, L. (2000). Professional Development Model for Exploring the National Science Education Standards, Science Educator 49.

Bogaski, C. S. (2015). A private school leadership perspective on highly qualified middle school science teachers. Florida Atlantic University.

Brownstein, E. M., Allan, E., Ezrailson, C. M., Hagevik, R. A., Shane, J. W., \& Veal, W. R. (2009). Alignment of the 2003 nsta standards for science teacher preparation with the ncate assessment system. Journal of Science Teacher Education, 20(5), 403-413.

Brownstein, E. M., Allan, E., Hagevik, R., Shane, J., \& Veal, W. (2009). Understanding and using the 2003 NSTA science teacher preparation standards for NCATE accreditation or state approval. Journal of Science Teacher Education, 20(4), 307-311.

Byers, A., Koba, S., Sherman, G., Scheppke, J., \& Bolus, R. (2011). Developing a web-based mechanism for 
assessing teacher science content knowledge. Journal of Science Teacher Education, 22(3), 273-289.

El-Baz, Khaled Salah (2005). Developing the science curriculum in the preparatory stage in light of learning standards, First Edition, Al Ain, United Arab Emirates: University Book House

Friedrichsen, P. J., Linke, N., \& Barnett, E. (2016). Biology Teachers' Professional Development Needs for Teaching Evolution. Science Educator, 25(1), 51.

Hagevik, R., Veal, W., Brownstein, E. M., Allan, E., Ezrailson, C., \& Shane, J. (2010). Pedagogical content knowledge and the 2003 science teacher preparation standards for NCATE accreditation or state approval. Journal of Science Teacher Education, 21(1), 7-12.

Huber, R. (2001). The In pact of standards Guided Equity and problem solving Institute on participating science teachers and their students. North Carolina Journal of Teacher Education.

Lulu, F. (2007). The quality of physics subjects included in science books in the lower elementary stage, Faculty of Education, Islamic University, Gaza.

Nashwan, Y. H. (2001). New in Science Education, "Second Edition, Amman, Jordan: Dar Al Furqan. Science", 9th Scientific Conference" Obstacles of Scientific Education in the Arab World", Egyptian Society for Scientific Education, vol. Secondary Strategies for the Development of Scientific Culture ", (Translated by Jamal Aldin Mohamed Abdel Hamid) Trowbridge, Billy and Pepe, Rodger and Powell, Janet (2004). Teaching science in schools.

Veal, W. R., \& Allan, E. (2014). Understanding the 2012 NSTA science standards for teacher preparation. Journal of Science Teacher Education, 25(5), 567-580.

Wellembi, B. (2012): NTSA For Sciences Teachers. Educational Sciences Journal, (2). California University.

Zaytoon, K. A. H. (2004) Teaching Science for Understanding Constructional Vision. Second Edition, Cairo, Egypt: The World of Books.

Zoubi, T., \& Salamat, M. K. M. (2008). The Teachers' Ownership of Jordan's Standards for the Professional Development of Teachers from Their Point of View and from the Perspective of School Principals and Science Supervisors. Sharjah Journal of Humanities and Social Sciences, 42.

\section{Copyrights}

Copyright for this article is retained by the author(s), with first publication rights granted to the journal.

This is an open-access article distributed under the terms and conditions of the Creative Commons Attribution license (http://creativecommons.org/licenses/by/4.0/). 